\title{
Research of Corruption in the Education System
}

\author{
Irina I. Frolova ${ }^{1}$ \\ ${ }^{1}$ Institute of economics, management and law (Kazan) branch in Naberezhnye Chelny, Russian Federation \\ Correspondence: Irina I. Frolova, Naberezhnochelninskaya street, 31, Naberezhnye Chelny, 423810, Russian \\ Federation. E-mail: fii@mail.ru
}

Received: June 9, 2014 Accepted: July 1, 2014 Online Published: September 28, 2014

doi:10.5539/ass.v10n20p21 URL: http://dx.doi.org/10.5539/ass.v10n20p21

\begin{abstract}
The article presents the results of sociological research to assess the level of corruption in the education system. The survey participants were experts-teachers, post-graduate students, students, schoolchildren, parents of children attending preschool institutions and schools. The goal of research to assess the level of corruption in the monitoring mode in the system of "preschool educational establishment-school-University-postgraduate study" in Naberezhnye Chelny. The results shows that among the respondents $78 \%$ of the experts, $83,8 \%$ of students, $57.5 \%$ of students, $70 \%$ of graduate students and $61 \%$ of parents of children of preschool institutions fall into the corruption situation. At different stages of the educational process forms of corruption acquire the various forms.
\end{abstract}

Keywords: corruption, the education system, preschool institutions and schools, educational process, post-graduate students, experts

\section{Introduction}

The relevance of the study is due to the fact that the development of corruption in Russia at the present stage has reached a high level. Corruption is raised in various spheres of life, including in education. It destabilizes the prevailing moral foundations of society, violates the principles of social justice and equality. The population has lost the faith in justice (Frolova, 2008).

Corruption in education violates the principles of social justice and equality of all participants of educational process. In addition, corruption negatively affects the image of any educational institution in the system: "preschool educational establishment-school-University", hampers development and reduces the effectiveness of management.

Education is one of the important components of quality of life. So, a large proportion of corruption observed there (Frolova, 2010).

The author conducted expert interviews of teachers of educational institutions of Naberezhnye Chelny, surveyed of graduate students, students, schoolchildren, parents of children attending preschool institutions and schools in the period from 2009 to 2013. The sample of research in 2010 amounted to 840 people, in 2013-870 people.

The goal of research: to assess the level of corruption in the monitoring mode in the system "preschool educational establishment-school-University-postgraduate study" in Naberezhnye Chelny.

The objectives of research:

1) To review the literature on the problems of investigation of corruption in educational institutions in the system of "preschool educational establishment-school-University-postgraduate study".

2) To analyze the results of sociological research.

3) To formulate conclusions and develop the main directions of improvement of anticorruption work.

\section{Materials and Methods}

Methods of research: the questionnaires, expert survey, analysis of secondary information.

During the processing of empirical data statistical methods, systems analysis were applied, methods of ranking, classification, grouping were used.

Scientific novelty of the investigation consists of that we carried out the sociological research to assess the level of corruption in the system "preschool educational establishment-school-University-postgraduate study" in 
Naberezhnye Chelny for the first time.

\section{Results}

The results of the research have applied character and can be the basis for the development of programmers for prevention and overcoming of corruption in educational institutions in the system: "preschool educational establishment-school-University-postgraduate study".

The study presents a small slice of research results from 2010 till 2013.

The study 2013 participated 870 people: 50 experts with higher education who work in the system of pre-school educational institution-school-University-postgraduate study; 500 students, 200 high school students, 20 postgraduate students; 100 parents of children attending preschool institutions.

Among the interviewed $78 \%$ of the experts, $83.8 \%$ (419 persons) students, $57.5 \%$ of the students (115 people), $70 \%$ of graduate students and $61 \%$ of parents of children from pre-school educational institution fell into corruption situation.

Among the different groups of respondents, students, experts in the system of the entire education chain and graduate students have got mostly in the corruption situation. Senior pupils are the least.

At different stages of the educational process forms of corruption acquire various forms. So, such types and forms of corruption, as the imposition of mandatory paid services ( $92 \%$ of experts and $76 \%$ of parents); the conclusion of contracts on a voluntary donation ( $87 \%$ of parents and $92 \%$ of the experts) are dominated in pre-school institutions in 2013.

A significant discrepancy of the results of research on the manifestations of corruption in kindergartens are associated with the presence of counting "dead souls", which turns the salary $(64 \%$ of experts against $2 \%$ of parents), as well as gratitude to the official for a call to pre-school educational institution and assistance for receipt of a child in kindergarten (38\% of experts against $12 \%$ of parents).

According to the study, the school is also a place of corruption crimes. Without exception, all the respondents in 2010 and 2013, and noted that the most common form of corruption in the school are charges of money on mandatory gifts to teachers for all holidays and "voluntary" contributions and donations. Monitoring data of the survey results indicate that significantly increased the percentage of such form as the imposition of tutoring from $56.5 \%$ to $83 \%$ among schoolchildren and $70 \%$ to $84 \%$ by the experts. The imposition of fee-based courses to prepare for the exam also tends to increase.

Positive dynamics is the reduction of such bribery as a bribe for admission to a good school, which may be associated with the entry into force of the new rules of admission of first-graders to school.

The higher education system is the shadow market in which revolves a lot of money. Corruption in higher education is a system of informal relations between participants of corruption through abuse of authority of different actors (Frolova, 2010). In 2010, an increase of $16.2 \%$ of the respondents answered that reject corruption in high school and believes that it infringes their rights, interests and freedoms, in 2013, this indicator improved to $25.8 \%$.

According to experts, in most cases, all forms of corruption in the University there is a positive trend. Least of all in 2013, compared with 2010, used such schemes as the provision of services to the University, registration, sponsorship bribes to teachers. The results of the survey among students also on these items showed a tendency to decrease. In 2 times fewer students began to give gifts to teachers (31\% in 2013, against 64\% in 2010).

The data of the 2010 survey show that the initiator of corruption was often the students themselves (51.6\%), relatives $(14.2 \%)$ and the teachers themselves $(34.2 \%)$, which hinted at, gift or intentionally didn't put a positive evaluation. In 2013 , the picture is slightly changed: $46.4 \% ; 13.2 \%$ and $40.4 \%$, respectively.

In $2010,88.4 \%$ of the respondents said that the transfer of money was made through an intermediary. Only $11.6 \%$ of respondents gave the money personally to the teacher. Among intermediaries half of the respondents (51.6 per cent) distinguished workers of the Dean's office, in $23 \%$ of cases the intermediaries were other teachers or staff of the University, and the rest of $25.4 \%$ were mediators from the student's environment (headman or other members of the group). In 2013, the students indicated that $5.6 \%$ of respondents gave the money personally to the teacher, which is almost 2 times less than the results of previous studies. Intermediaries in the transfer of money has not changed: the workers of the Dean's office (50.4 percent), other teachers or staff of the University (24.4\%), students (25.2\%).

The results of the study in 2010 showed that only $7.2 \%$ of respondents are ready to declare the fact of the bribe. 
The main reasons to conceal the fact of bribery students named the following: the fear of reprisals on the part of the teacher (34.6\%), fear of the University administration (30.4\%), unwillingness to retake the exam, which was paid (27.2 \%), fear of criminal responsibility (7.8\%). In $201316.6 \%$ of students surveyed expressed willingness to report the fact of the bribe, provided that they will not be punished by law.

Post-graduate students and experts who participated in the study reported on the specifics of the types of corruption in graduate school. In 2013, experts note an increase in corruption in all types: bribe reviewers for a positive review, the bribe for assessment from the lead organization, thanks to the Director for scientific management, etc. Significant growth of corruption has occurred at the expense of bribes for the promotion of the protection period for urgent publication in journals of State Commission for Academic Degrees and Titles, the bribe for the candidate examinations for admission to graduate school.

In 2013 there is such kind of corruption schemes, as the imposition of publication in Scopus and other systems with the international index of citing in collaboration with money: $20 \%$ of graduate students and $32 \%$ of experts pointed to this fact.

Thus, the informal sector of pre-school, school and higher education is constantly expanding. The results of sociological research concretize the problems of corruption in the pre-school educational institution, school, and University graduate school, different in Naberezhnye Chelny. The obtained results can serve as the basis for the development and correction of the activities of existing programs to overcome corruption.

\section{Discussion}

Theoretical overview of the problem of corruption in educational institutions.

1) According to the Federal law dated 25.12.2008 N 273-FL (as amended on 30.09.2013) "On combating corruption", corruption is:

a) abuse of office, bribery, abuse of authority, commercial bribery or any other illegal use of a natural person of his official position contrary to the legitimate interests of society and state in order to receive benefits in the form of money, values, other property or services of property character, other property rights for themselves or third parties or illegally providing such benefits to an individual other physical persons;

b) the conduct set forth in subparagraph "a", on behalf or in the interest of the legal person;

2) Anti-corruption activities of the Federal bodies of state power, bodies of state power of subjects of the Russian Federation, local authorities, civil society institutions, organizations and individuals within their authority:

a) to prevent corruption, including on the detection and subsequent removal of causes of corruption (prevention of corruption);

b) detection, prevention, suppression, disclosure and investigation of corruption offences (control of corruption);

c) minimizing and/or eliminating consequences of corruption violations (Federal law dated 25.12.2008).

In the Federal law of 17.01.1992 N 2202-1 (as amended on 01.10.2013) "On Prosecutor's office of the Russian Federation" of the present article 41.8. (the Federal law from 21.11.2011 N 329-FZ) penalties for failure to comply with the restrictions and prohibitions, requirements on preventing or resolving conflicts of interest, and failure to perform duties established in order to counter corruption (Federal law from 17.01.1992).

Kudashkin A. V. notes that corruption is a complex social phenomenon with various ways that are not always obvious. A variety of used formulations of the concept of "corruption" is not always allows to reveal all the essential features of this phenomenon. It is generally accepted understanding of corruption as the use by the official of their powers and the rights entrusted it for personal benefit, contradicting the established rules. However, it should be noted that this approach may not lead to the formation of the system of principles of combating corruption, because it is not possible to accurately determine the criteria of corruption, and particularly of offences. As a social phenomenon, corruption is rather many-sided. Understanding of corruption only as committing corruption crimes does not match the realities of corrupt practices that, in turn, contributes to the formation of an effective system to counter it (Kudashkin, 2012).

Corruption is raised in any segment of the educational process. Each link in the system of preschool education-school-University-postgraduate study" has its own specifics.

Official scientific and statistical research on corruption in the system of preschool education is still not enough. However, the experience of the Republic of Tatarstan shows that adopted anti-corruption measures are effective. So, electronic queue in kindergartens has allowed not only reducing the number of persons waiting for 30-35\% and arranging to preschool for all children over three years, but to make the process of moving in the queue of a 
transparent and clear. All this has a significant preventive effect on domestic corruption (Badrutdinov \& Rakhimov, 2012).

Rooting out corruption in modern Russian education contributed to the deterioration in the 1990-ies the socio-economic situation in the country, gaps in legislation, and mostly tacit consent and approval in respect of bribery position of teachers and heads of schools. Russian experts, speaking about the reasons for the emergence and spread of corruption in schools across the country, paying special attention to the fact that corruption facts are difficult to prove. First, this is facilitated by the many loopholes in the legislation, among which the permit to create the fund of support of schools", to make "voluntary" contributions to the school development from parents, students children, to make gifts of teaching staff, to make charges of money for protection, equipment, additional classes and other secondly, none of the participants of the educational process in practice is not interested in revealing corruption crimes (http://www.memoid.ru).

The order "On amendments to the Order of reception of citizens in educational institutions, approved by the order of the Ministry of education and science of the Russian Federation of February 15, 2012, N 107", published in "the Russian newspaper", modifies launched since the spring of 2012 recording of first-graders. According to a current procedure, in the first place is guaranteed for those children who live on are attached to the school territory. For them, the recording began on 1 March and continued until July 31 . All other record in secondary schools in the presence of empty seats in the period from 1 August to 5 September (http://www.memoid.ru).

The tutoring is rising at schools, a tool which is lower estimates and strong recommendations from teachers to engage in tutoring. This is especially true was when the students are preparing for the exam. It should be noted that parents often turn a blind eye to bribery, "voluntary" contributions, etc. because they are afraid that it will affect the child. Then the parent will have to interfere not only with the teacher and the school administration, but also with parents of other children. Therefore it is easier for them to comply with the requirements of the system and to pay, which contributes to corruption.

Corruption in the University can be manifested in various forms: the abuse of power of the teacher on the student to obtain benefits for personal purposes, the issuance of diplomas to specialists without professional adequacy, sale and use of term papers and final qualifying works, made to order; extortion of money for a positive assessment, the imposition of a commercial consulting, selling author of the books of teachers, etc. One of the principles of sharing in higher education is mutual advantage, that is, each participant benefits. In the sphere of higher education can observe the phenomenon of "competing teachers" [http://www.econ.yale.edu], where it is possible to replace a teacher at the exam or test. In addition, one of the hidden or latent forms of corruption in the University is the exchange of services, which may occur between any entities (deans, heads of departments and so on). There is no exchange of money, but can violated the law or the rules of work at the University.

One of the principles of sharing in higher education is mutual advantage, that is, each participant has benefits. In the sphere of higher education we can observe the phenomenon of "competing teachers" (Osipyan, 2009), where it is possible to replace a teacher at the exam or test.

The results of the survey of experts in 2010 confirmed that in universities thrives hidden form of corruption. Corruption extends to management of higher education institution, for example, the presence of fictitious teachers and paying them wages (20\%), misuse of funds, premises and other assets of the institution (30\%), bribery inspection bodies in the accreditation of educational institutions (50\%) (Frolova, 2010).

Thus, in 2010 the results of the author's sociological survey among the students showed that the presents are the mechanism of influence on the loyalty of a University teacher when setting a positive assessment. Answering the question: «have you ever had to give the teachers gifts?» more than half of the respondents $(64 \%)$ answered positively. Of them $93.8 \%$ noted that the gift was presented before the exam or assessment. $24,8 \%$ of respondents rent money on a gift to the teacher, even if they are sure that they will pass it. The main reason of this was generated by the norm of group behavior-«be like everyone else» (Frolova, 2010). However, in 2013, this situation has significantly changed-already $31 \%$ of respondents are similar samples pointed to the fact gift to the teacher.

E.V. Pulyaeva identifies the following factors giving rise to legal problems of counteraction of corruption in the provision of educational services:

- the absence of clear regulation of the status of bodies of education management;

- the unsettlement of the activities of the education authorities when providing services in the sphere of education; 
- the «forking» unified state powers in the sphere of education between several Federal bodies of Executive power;

- the presence of border areas, for legal regulation requiring any intervention in the competence of another Federal body the Executive power, or interaction with him;

- the selection as a separate stage in the mechanism of rendering of services of a number of necessary actions alleged by the very fact of this service, and giving them some independence;

- the two statutory mechanisms for applying for educational services, essential for applicants which is of the order of submission of documents;

- the absence of a normative legal act governing the appearance of the legal act that must be taken in certain the aggregate situations in the framework of educational relations, procedure of its adoption by the Executive power;

- the corrupt nature of the norms of law to be applied;

- the uncertainty of regulatory requirements in the law that refers only to the need to adopt a legal act without defining its content component, which allows for a dual interpretation;

- the creation of divisions in the structure of educational organizations (goal-ensuring transparency, openness, transparency of activity), such as student councils and forms of government, but in fact under the control created their educational organizations;

- the opacity of the legal status subordinate to the authority in the sphere of education organization, created to ensure the provision of educational services;

- the informational closeness of the procedures related to the provision (denial of provision of educational services (Pulyaeva, 2012).

V. V. Kovalev believes that, given the high latency of corruption practices in the educational process in the universities, the principal means of monitoring should be polls with an indispensable condition of their flawless organization and conduct, and when truly scientific interpretation of their results.

An indispensable condition must be, first, the survey it themselves subjects of educational process as potential or actual participants in corrupt practices. And it must be not only students but also teachers, officials of the University. Secondly, the survey should cover their own actions subjects, not information that «someone about something somewhere once heard».

Third, the content of the questions (especially the proposed teachers) should be correct. Finally, absolute anonymity of the respondents in which they must be absolutely sure. Performance indicators (such as «often», "rarely", "always", "never") or not should be used in such surveys, or to take them purely supportive role. However, such surveys are extremely important to enlist the support of the leadership of the University, overcoming legitimate wary of the reaction due to understandable concerns turn out to be worse than others. Finally, when conducting interviews should not be limited to relations "teacher-student", indicating potential or existing corruption practices in addressing and other related students vitally important issues (e.g., lodging, extending the session, granting the right of individual lessons and so on). Such "corruption niches" in the practice of high school a few dozen, but they still remain without attention in the shadow toll of tests and examinations (Kovalev, 2011).

One of the forms of corruption in "dissertation is on a turnkey basis" is the complex corruption service, which consists in the fact that the competitor of a scientific degree for certain remuneration (usually for money, but it is possible to provide other property, works, services) exempted from any concerns related to the desired degree (Skoblikov, 2011).

Nosakova Y. S. considers that the effectiveness of the fight against corruption is not so much in the adoption of anti-corruption legislation and its implementation in practice, as in the formation of anti-corruption awareness through the development and implementation of appropriate measures. Despite the importance of application of this way of combating corruption, indicated a system of measures is still missing. Moreover, the notion of anti-corruption consciousness, signs, types, factors influencing its formation, also not studied (Noskova, 2012).

Thus, corruption is raised in any segment of the educational process. Each link in the system of preschool education-school-University-postgraduate study" has its own specifics.

\section{Conclusion}

To improve the organization of anti-corruption work in educational institutions of the city of Naberezhnye Chelny proposed: 
1) To develop in PRESCHOOL institutions, schools, universities programme on fighting corruption, with separate areas for cooperation of employees of educational institutions (EI) and participants of the educational process (EP) with law enforcement.

2) To ensure a broad and open discussion on the website of the EI in a network the Internet of the problem of corruption, surveys, to provide the possibility of open reviews with the creation of tabs "the Fact of corruption" on the websites of the EI.

3) To eliminate the human factor in picking the order of receipt of the child in the pre-school educational institution from the leadership of the pre-school educational institution and municipal education systems through the use of fully automated information programs.

4) Organization of system of a feedback with all parties to the ЕР. Внедрить в практику "телефон доверия" (The order of the Russian Ministry of 11.12.2012).

5) Optimization of the control functions of management of the shelter.

6) To develop a mechanism of reacting to the facts of corruption in the shelter.

7) Improvement of the information system of the EI.

8) Organization and holding of the anti-corruption monitoring.

9) Information campaigns can be carried out by conducting round tables, straight lines with the representatives of the shelter and authorities, press conferences, publication of scientific research results in the media, etc (Frolova, 2012).

10) To develop mechanisms, which will provide opportunities for messages about the facts of corruption in any segment of the educational chain and the protection of persons providing such information. So, the Federal service for supervision in education and science adopted additional measures (Order from 15.05.2013).

11) To observe the established order of notification (Order from 31.03.2011) the representative of the employer (the employer) on the facts of a case in order to declination of the Federal state civil employee of the Federal service for supervision in education and science for committing corruption offences.

12) To ensure the annual holding on the basis of Federal state educational institution of higher professional education "the Russian Academy of national economy and state service under the President of the Russian Federation" educational-methodical seminars for teachers of educational institutions implementing educational programs on anti-corruption subjects according to the program coordinated with the Administration of the President of the Russian Federation (The decree of the President of the Russian Federation of 11.04.2014).

13) To develop a system in each educational institution (Terekhova, 2011), the principles of which should be the following: intolerance to corruption in all forms, unconditional compliance and the inevitability of punishment.

14) To implement anticorruption educational program-trained to unprepared listeners basic notions of anticorruption topics, corruption processes and phenomena in the shelter.

\section{References}

Badrutdinov, M. S., \& Rakhimov, S. F. (2012). The Fight against corruption: The experience of the Republic of Tatarstan. Journal of Russian law, 12.

Buscaglia, E., \& van Dijk, J. (2003). Controlling organized crime and Corruption in the public sector. Retrieved June 17, 2014, from http://www.unodc.org/pdf/crime/forum/forum3_Art1.pdf

Dorovskaya, N. (2011). Corruption in schools of post-Soviet Russia. Retrieved June 17, 2014, from http://www.memoid.ru/node/Korrupciya_v_shkolah_postsovetskoj_Rossii

Federal law dated 25.12.2008 N 273-FZ. (2013, September 30). On combating corruption. Mode of access: Consultant plus.

Federal law from 17.01.1992 N 2202-1. (2013, July 23). On Prosecutor's office of the Russian Federation. Mode of access: Consultant plus.

Ferraz, C., \& Fina, F. (2007). Electoral Accountability and Corruption in Local Governments: Evidence from Audit Reports. Retrieved June 15, 2014, from http://www.econ.yale.edu/seminars/develop/tdw07/finan -071112.pdf

Frolova, I. I. (2008). Corruption in the health sector in Tajikistan: Results of the expert poll. Investigator, 3, 58-59. 
Frolova, I. I. (2010). Corruption in higher education: The results of concrete sociological research. Urgent problems of Economics and law, 4(16), 147-149.

Frolova, I. I. (2012). Corruption in government: An expert poll results. Urgent problems of Economics and law, 4, 104-107.

Kovalev, V. V. (2011). ABOUT the specifics of monitoring of corruption practices in educational process of higher educational institutions: Administrative and municipal law, 7. Mode of access: Consultant plus.

Kudashkin, A. V. (2012). Anti-Corruption expertise: Theory and practice: Scientific-practical manual. Mode of access: Consultant plus.

Noskova, Y. S. (2012). Role of education in the formation of anti-corruption awareness of students: Legal world, 4. Mode of access: Consultant plus.

Order from 15.05.2013 N 1376-09. (n. d.). On additional measures on realization of the Federal law on combating corruption in the Federal service for supervision in education and science. Mode of access: Consultant plus.

Order from 31.03.2011 N 812. (n. d.). On approval of the Procedure of notification of the representative of the employer (the employer) on the facts of a case in order to declination of the Federal state civil employee of the Federal service for supervision in education and science for committing corruption offences. (Registered in Ministry of justice of the Russian Federation 17.05.2011 N 20769). Mode of access: Consultant plus.

Osipyan, A. L. (2009). Terminological dictionary corruption in higher education. Retrieved from http://people.vanderbilt.edu

Pulyaeva, E. V. (2012). Legal problems of the struggle with corruption in the provision of education services. Journal of Russian law, 11. Mode of access: Consultant plus.

Skoblikov, P. (2011). Corruption in science: Dictionary informal terms and concepts. Retrieved June 18, 2014, from http://www.mgimo.ru/files/153321/Skoblikov.pdf

Terekhova, A. G. (2011). Transformation of compliance and risk management in the system of internal control. Retrieved June 18, 2014, from http://www.reglament.net/bank/control/2011_1_article_3.htm

The decree of the President of the Russian Federation of 11.04.2014 N 226. (n. d.). On the National plan of counteraction of corruption in 2014-2015 years. Mode of access: Consultant plus.

The order of the Russian Ministry of 11.12.2012 N 1034. (n. d.). About the Position statement about the "telephone hotline" on combating corruption in the Ministry of education and science of the Russian Federation. Mode of access: Consultant plus.

\section{Copyrights}

Copyright for this article is retained by the author(s), with first publication rights granted to the journal.

This is an open-access article distributed under the terms and conditions of the Creative Commons Attribution license (http://creativecommons.org/licenses/by/3.0/). 